\title{
Regime Interaction and the Protection of Refugees during COVID-19
}

\author{
Thomas Mulder*, Gabrielle Simm ${ }^{* *}$ and Sarah Williams ${ }^{* * *}$
}

The COVID-19 pandemic has highlighted the challenges of protecting refugee populations where a combination of factors, such as conflicts and a pandemic, produce humanitarian emergencies. For example, after the first Covid-19 case in a Rohingya refugee camp in Bangladesh was confirmed, the camp was placed in lockdown. ${ }^{1}$ However, due to the overcrowded conditions, social distancing was not possible. There was a shortage of masks, soap and disinfectants and limited access to health care professionals and facilities such as hospital beds, as well as appropriate personal protective equipment to ensure the safety of health professionals, officials and refugees. ${ }^{2}$ Complicating these practical challenges are the multiple legal regimes that potentially apply to those individuals in refugee camps during a humanitarian emergency. The existence of multiple legal regimes raises the possibility of overlapping or conflicting obligations as well as "gaps" in the protection of refugees. Different rules and institutions may pose problems for policymakers and practitioners that could cause confusion and delay protection. The complex legal situation also feeds into long-standing anxieties within the discipline about the risk of fragmentation of international law into specific regimes in the absence of clear guidance on regime interaction.

This article seeks to explore regime interaction through a focus on the protection of refugees in camps. The study of regime interaction in a humanitarian emergency is particularly significant as the pandemic has highlighted how a health emergency exacerbates pre-existing inequalities. Two review

\footnotetext{
* Thomas Mulder LL.M., Unsw, Sydney.

** Gabrielle Simm, University of Technology Sydney, Faculty of Law.

*** Sarah Williams, Unsw, Sydney.

1 Julhas Alam, '1st COVID-19 Case Detected in Rohingya Camps in Bangladesh' AP (15 May 2020) <https://apnews.com/article/f6ad74dicodcfb784b5a245e762e3b3e> last accessed (as any subsequent URL) on 10 July 2021.

2 Amy Bainbridge and Omar Faruque, 'A coronavirus crisis is building inside Cox's Bazar, the world's largest refugee camp' ABC News (16 June 2020) <https://www.abc.net.au/ news/2020-o6-16/rohingya-refugees-coxs-bazar-coronavirus/12356o46>.
} 
mechanisms commissioned by the World Health Assembly (WHA) ${ }^{3}$ following Covid-19, the Independent Panel for Pandemic Preparedness and Response $(\text { IPPPR })^{4}$ and the Review Committee on the Functioning of the International Health Regulations (2005) during the COVID-19 response (IHR 2005 Review Committee), ${ }^{5}$ have called for reform of key legal instruments, including the adoption of a new framework convention for pandemic response and preparedness. We argue that reform of one regime, i.e. global health law, should not be done in isolation from intersecting regimes.

After discussing relevant literature on regime interaction (section 2), we identify the different legal regimes potentially applicable to refugee camps during the COVID-19 pandemic. The focus is on those regimes applicable to the refugees in a camp, rather than regimes such as international humanitarian law and international criminal law that focus on the circumstances that prompt displacement in the first place. Section 3 explores how those legal regimes interact, if at all, including the application of any relevant rules of regime interaction, before section 4 offers analysis. This article expands our understanding by exploring regime interaction in a new context: a humanitarian emergency that requires a focus on the protection of individuals, rather than the rights and interests of states.

\section{$2 \quad$ Regimes and Regime Interaction}

This article draws on the international law literature on regime interaction, starting with the Conclusions of the 2006 International Law Commission Study Group on the Fragmentation of International Law (ILC Study Group). The definition of a regime is contested. The ILC Study Group identified three, progressively broader definitions of a regime, also referred to as a 'self-contained' or 'special' regime:

(1) 'sometimes violation of a particular group of (primary) rules is accompanied by a special set of (secondary) rules concerning breach and reactions to breach.'

3 WHA 'COVID-19 Response' (19 May 2020) WHA73.1, para. 10.

4 The Independent Panel for Pandemic Preparedness \& Response, 'COVID-19: Make it the Last Pandemic' (May 2021) ('IPPPR').

5 wно, 'Report of the Review Committee on the Functioning of the International Health Regulations (2005) during the COVID-19 response' (5 May 2021) A74/9 Add.1 ('IHR 2005 Review Committee'). 
(2) 'sometimes (...) a special regime is formed by a set of special rules, including rights and obligations, relating to a special subject matter. Such rules may concern a geographical area (e.g., a treaty on the protection of a particular river) or on some substantive matter (e.g., a treaty on the regulation of the uses of a particular weapon). Such special regime may emerge on the basis of a single treaty, several treaties, or a treaty and treaties plus non-treaty developments (subsequent practice or customary law)'.

(3) 'Finally, sometimes all the rules and principles that regulate a certain problem area are collected together so as to express a "special regime." Expressions such as "law of the sea", "humanitarian law", "human rights law", "environmental law" and "trade law" give expression to some such regimes. For interpretative purposes, such regimes may often be considered in their entirety' ${ }^{6}$

In this article, we adopt the third and broadest definition as this understanding of a regime is the most inclusive and is most widely used. The literature on regime interaction emphasises that regimes are not just a body of law, but also include the actors and institutions that create, interpret and apply that law. ${ }^{7}$ Institutions can include courts and tribunals, while actors include states and sometimes non-state actors, particularly international organisations, technical experts, NGOs, secretariat staff, tribunal members and others. ${ }^{8}$

Our primary focus is the relationship or interaction between one or more regimes, rather than the interaction of norms within a regime. The ILC Study Group identified two general types of relationships between 'rules and principles that are both valid and applicable' to a situation. The first type of relationship is one of interpretation 'where one norm assists in the interpretation of another (...) [so] both norms are applied in conjunction. ${ }^{9}$ The second type of relationship is one of conflict 'where two norms are both valid and applicable point to incompatible decisions so that a choice must be made between them.10 ${ }^{10}$ The latter relationship assumes a hierarchy, such that one

6 ILC, 'Fragmentation of International Law: Difficulties arising from the Diversification and Expansion of International Law' (18 July 2006) A/CN.4/L.7O2, 11-12, para. 12.

$7 \quad$ Ibid., 11-12.

8 Margaret A Young, 'Introduction' in Margaret A Young (ed), Regime Interaction in International Law: Facing Fragmentation (CUP 2O12) 1, 6-7.

9 ILC, 'Yearbook of the International Law Commission', 2006, vol. II (Part Two), 178, para. (2).

$10 \quad$ Ibid. 
regime must take precedence over the other, which scholars have described as a conflict or collision between regimes.

The ILC Study Group set out a hierarchy of rules recognised by international law and identified a series of principles to assist in minimising and resolving conflict between regimes, including the treaty interpretation provisions of the Vienna Convention on the Law of Treaties. ${ }^{11}$ While there is no hierarchy of sources as between treaties, customary international law and general principles of law, ${ }^{12}$ rules of jus cogens are superior and override inconsistent rules. ${ }^{13}$ Further, the UN Charter takes precedence over inconsistent treaties by virtue of article 103 of the Charter, with binding decisions of the Security Council also enjoying this status. ${ }^{14}$ The principle of lex specialis provides that more specific norms take priority over general norms in the event of a conflict. ${ }^{15}$ According to the principle of lex posterior, later law supersedes earlier law where all parties to an earlier treaty are also party to a later treaty. ${ }^{16}$ However, the principle of lex posterior does not necessarily apply to treaties in different regimes. ${ }^{17}$ The principle of harmonisation, i.e. interpreting several relevant norms so as to give rise to 'a single set of compatible obligations' to the extent possible, is another means of resolving conflicts, largely by seeking to avoid finding a conflict in the first place. ${ }^{18}$ We argue here that the principle of harmonisation also plays a significant role in the first type of relationship, where there is no underlying conflict.

Conflicts can also be avoided where states include savings or conflict of law clauses in treaties that specify relations between treaties and how conflicts are to be resolved, including reference to dispute settlement as appropriate. ${ }^{19}$ Disputes regarding conflicting obligations should be resolved by the dispute settlement mechanism provided within regimes, and in conflicts between regimes, 'special attention should be given to the independence of the means of settlement chosen'. ${ }^{20}$ Courts or tribunals are most likely to address regime

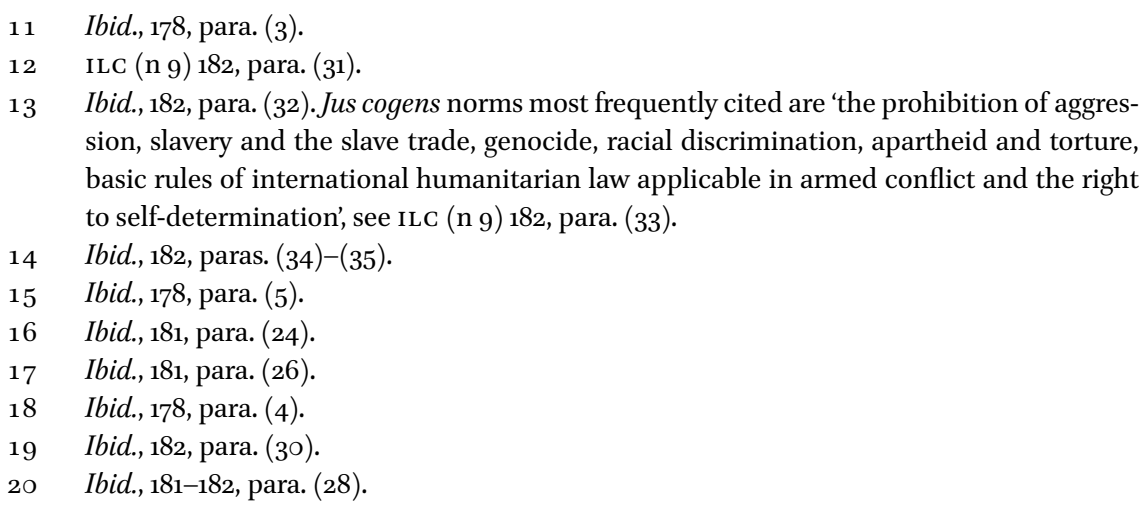


interaction where states are unable to agree on how to resolve a regime conflict; whereas using a regime to interpret another regime may be less likely to result in international dispute resolution. We suggest that the rules and commentary on regime interaction are accordingly skewed to reflect relationships of conflict, while in everyday practice relationships of mutual interpretation are more common and less likely to produce records and rules arising from formal dispute settlement.

Academic literature has also analysed hierarchy and relationships more generally between regimes. To date, studies of regime interaction have focussed most on trade law, investment law, law of the sea, environmental law, and human rights law. ${ }^{21}$ With the exception of environmental law, these regimes are well equipped with international or regional institutions to facilitate dispute settlement based on a decision about what the relevant law is and how it applies to the dispute. ${ }^{22}$ These are in addition to domestic courts and the International Court of Justice (ICJ), which has general jurisdiction over interstate disputes. We argue that, perhaps as a result of the dispute settlement mechanisms developed by states to protect their interests in these regimes, the rules and literature demonstrate a bias towards assuming conflict between regimes and hence a search for rules to resolve such conflicts. ${ }^{23}$ By contrast, this article explores regime interaction in a different context - a refugee camp during a pandemic - where the regimes, being motivated by protection, are less likely to conflict and hence there is no need for dispute resolution. Another important distinction is that states are perhaps less likely to assert their interests in a humanitarian relief situation, possibly excepting a host state wishing to receive fewer displaced persons. In that case, a host state is unlikely to engage international dispute mechanisms, even if available, but

21 James Crawford and Penelope Nevill, 'Relations between International Courts and Tribunals: the Regime Problem' in Young (n 8), 235 and references therein. See further Margaret A Young, Trading Fish, Saving Fish: the interaction between regimes in International Law (Cambridge University Press 2011).

22 Some examples include International Tribunal on the Law of the Sea and arbitration under UN Convention on the Law of the Sea for disputes regarding law of the sea, regional human rights courts in Africa, Europe and the Americas and individual petitions to UN human rights treaty bodies, World Trade Organization panels and appellate body in trade law, investor state dispute settlement under the International Convention on the Settlement of Investment Disputes, and the UN Commission on International Trade Law model rules on arbitration, along with other mechanisms provided in bilateral investment treaties to resolve investment disputes.

23 See, for example, Andreas Fischer-Lescano and Gunther Teubner, 'Regime-Collisions: the Vain Search for Legal Unity in the Fragmentation of Global Law' (2004) 25 Michigan Journal of International Law 999. 
more commonly will close or restrict access to its borders. Many states are not parties to relevant refugee or statelessness conventions, while even state parties are unlikely to face complaints being brought by other states about the former's failure to comply with its obligations.

This section identifies the regimes that are potentially applicable to refugee camps, both as a matter of law and those most likely to address the practical challenges raised. These are international refugee law (IRL);24 global health law (GHL); international disaster law (IDL); and international human rights law (IH RL). While there may be divergent views as to the status and content of these areas of law, for present purposes we accept that these sub-fields of international law satisfy the ILC's third definition of a regime. ${ }^{25}$ Given the limited focus of this article, the intention is not to provide a comprehensive study of each regime. Instead, we limit our discussion to the following issues drawing on factors identified in the literature on regime interaction. First, we consider the nature of the regime and its application generally. Second, we explore relevant substantive rules, in particular, obligations to provide medical care in refugee camps. Third, we analyse any rules regulating the interaction between regimes, including mechanisms for dispute settlement and any actors that may play a role in regime interaction. Due to space constraints, we have not considered relevant national law although it is an important potential source of rules and institutions.

\subsection{International Refugee Law Regime (IRL)}

The IRL regime comprises the $195^{1}$ Convention Relating to the Status of Refugees (1951 Convention) and 1967 Protocol Relating to the Status of Refugees (1967 Protocol), the Statute of United Nations High Commissioner for Refugees (UNHCR) and several General Assembly resolutions expanding the mandate of UNHCR, as well as various regional and bilateral instruments

24 We recognise that international statelessness law may also apply to people in refugee camps. However, given the substantive overlap between the two regimes and the role of UNHCR in both, for present purposes we are limiting our discussion to refugee law.

25 The International Health Regulations 2005, 23 May 2005 ('IHR 2005'), along with associated institutional practice, might be considered a special regime within the broader regime, being an example of the second type of regime identified by the ILC. 
and customary international law. ${ }^{26}$ The IRL regime focuses on the protection of refugees as well as their repatriation and resettlement, with the host state responsible for the safety and protection of refugees on its territory. Importantly, IRL recognises that protection of refugees and arriving at a long-term solution to a refugee problem is not the responsibility of the host state alone. Instead, the regime provides for burden-sharing, international collaboration and cooperation between all states parties, although these commitments are not reflected in legally binding obligations.

The 1951 Convention sets out basic minimum standards for the treatment of refugees by the host state, including providing that refugees shall enjoy the rights under the Convention without discrimination on the basis of race, religion or country of origin. ${ }^{27}$ Importantly, this does not preclude discrimination by the host state relative to its population based on refugee status. The 1951 Convention does not mention pandemics, nor does it directly address responsibility for the health of refugees and access to the health care system. However, the host state must provide to all refugees 'lawfully staying in their territory the same treatment with respect to public relief and assistance as is accorded to their nationals'. ${ }^{28}$ While much practice around this provision has concerned social security and welfare assistance, it is interpreted broadly and would include disaster assistance and access to responses to outbreaks of disease for refugees. ${ }^{29}$ The provision has two important caveats: first, it offers differential protection, being limited to those 'lawfully staying' on the territory of the host state, which will exclude some refugees from assistance. Second, the level of assistance required is the same standard that is accorded by the host state to nationals. Article 23 does not set a minimum level of assistance that refugees must receive; all that matters is that the assistance provided must not be lower than that given to the general population. This is an important limitation given the challenges of developing countries in providing health care during a global pandemic. Other regimes might provide guidance as to

26 Convention Relating to the Status of Refugees, 28 July 1951 ('1951 Convention'); Protocol Relating to the Status of Refugees, 31 January 1967 ('1967 Protocol'); UNGA, 'Statute of the Office of the United Nations High Commissioner for Refugees' (14 December 1950) A/REs/428(v) ('UNHCR Statute'); UNGA Res 31/36 (30 November 1976) UN Doc A/RES/31/36; Unga Res 36/125 (14 December 1981) UN Doc A/RES/36/125; UNGA Res 40/118 (13 December 1985) UN Doc A/RES/40/118.

$27 \quad 1951$ Convention (n 26) art. 3.

28 Ibid., art. 23.

29 See further, James C. Hathaway, The Rights of Refugees Under International Law (cuP $\left.2021^{2}\right) 1020-1021$. 
what the minimum standard of health care provision for both refugees and the general population might be.

Article 2 of the 1951 Convention confirms that an individual refugee has a general obligation to conform to the laws and regulations of the host state as well as to measures taken for the maintenance of public order. This supports the authority of the host state to adopt public health measures to address COVID-19 and requires individual refugees to comply with measures adopted. Moreover, while the 1951 Convention does not include a derogation clause as such; article 9 provides that a state party can, in a time of war or other grave or exceptional circumstances, take provisional measures in relation to an individual that it considers essential for national security. While the potential application of this provision in the context of COVID-19 is uncertain, ${ }^{30}$ it may provide a basis for the host state to restrict other rights accorded to refugees under the 1951 Convention, for example, the rights to education and association, but only on an individual basis. That is, provided any restriction adopted to respond to the pandemic as applied to an individual refugee is not based on a prohibited ground of discrimination, it would not violate the Convention. While this provision demonstrates that the regime attempts to deal with potential conflict of rules within the regime, article 9 does not provide any guidance as to how it should be interpreted and applied.

Even where the relevant treaty instruments may not apply directly when the host state is not a state party, the IRL regime applies due to the strong institutional role accorded to UNHCR under its Statute concerning refugee protection. ${ }^{31}$ The UNHCR Statute does not create binding obligations on states in terms of standards of protection. Instead, various General Assembly resolutions recognise that refugees are a concern of all states and call upon states to cooperate with UNHCR in the performance of its functions, including assisting the host state. ${ }^{32}$ The role played by UNHCR in camps is significant, with many responsibilities of the host government delegated to or exercised in cooperation with UNHCR. UNHCR is the lead agency on refugee protection

$30 \quad$ For further analysis, see Michelle Foster, Hélène Lambert and Jane McAdam, 'Refugee Protection in the CoviD-19 Crisis and Beyond: The Capacity and Limits of International Law' (2021) 44(1) UNSw Law Journal 104.

31 UNHCR Statute (n 26) art. 6(A)(ii). This is the same as the definition in art. 1 of the 1951 Convention, which is considered to be customary international law.

$32 \quad 1951$ Convention (n 26) art. 35. This is also reinforced by various UN General Assembly resolutions, for example, UNGA Res 74/130 (18 December 2019) UN Doc A/REs/74/13O: 'emphasizes the importance of active international solidarity and burden-and responsibility-sharing'. Identical or similar phrases appear in annual resolutions reaffirming commitment to IRL. 
and works in cooperation with government agencies, other UN agencies and NGOS. UNHCR thus fills the gap left by states not parties to core refugee treaties of providing protection to refugees in many circumstances, with the acquiescence and cooperation of states. ${ }^{33}$

IRL does not provide any formal rules on regime interaction between IRL and other regimes. However, the preamble to the 1951 Convention refers to the UN Charter and the Universal Declaration of Human Rights (UDHR), which have 'affirmed the principle that human beings shall enjoy fundamental rights and freedoms without discrimination' ${ }^{34}$ Moreover, the preamble highlights the endeavours of the UN to 'assure refugees the widest possible exercise of these fundamental rights and freedoms. ${ }^{35}$ Thus, IRL recognises that refugees are entitled to fundamental rights, including the right to health, and that IH RL intersects with the IRL regime. However, the core refugee treaties do not set out how or by whom those rights are to be realised and largely leave this for the IHRL regime to address.

IRL also offers little in the way of monitoring or dispute settlement options. The preservation of state sovereignty within the regime is reflected in the absence of an individual rights-based complaints mechanism, such as an international refugee court, or a strong enforcement mechanism. ${ }^{36}$ While the IRL regime recognises status determination procedures to engage the protection of the regime, there is no international mechanism that enables an individual to bring a complaint regarding standards of treatment. Instead, refugees must rely on national courts or the unlikely prospect of their state of nationality (or another state) bringing a claim before the ICJ. UNHCR is not an enforcement body as it has no mandate to monitor or enforce compliance with obligations under the IRL regime. Although UNHCR has a standard-setting role, it is unlikely that it will play a role in resolving conflicts of norms. In regional human rights systems, refugee claims have been brought before human rights institutions, particularly the European Court of Human Rights, and lodged before human rights treaty monitoring bodies, such as the UN Human Rights Committee. ${ }^{37}$ However, where UNHCR and other actors take the lead or a significant role in refugee protection, there is a further level of complexity.

\footnotetext{
33 Guy Goodwin-Gill and Jane McAdam, The Refugee in International Law (oup 2007 ${ }^{3}$ ) 428 .

$34 \quad 1951$ Convention ( $\mathrm{n} 26)$ preamble.

35 Ibid.

36 Anthony M North and Joyce Chia, 'Towards Convergence in the Interpretation of the Refugee Convention: a Proposal for the Establishment of an International Judicial Commission for Refugees' (2006) 25 Australian Yearbook of International Law 105.

37 Fanny de Weck, Non-refoulement under the European Convention on Human Rights and the UN Convention Against Torture (Brill 2016).
} 
UNHCR is not a party to human rights instruments and, therefore, the extent to which UNHCR is responsible, either individually or jointly with the host state, for providing minimum standards of protection (including health care) or can be held accountable for any failure to do so is unclear.

\subsection{Global Health Law}

The Constitution of the World Health Organization (wHo) states that the objective of the WHO is 'the attainment by all peoples of the highest possible level of health,', ${ }^{38}$ with health being more than the absence of infirmity; rather, it is 'a state of complete physical, mental and social well-being. ${ }^{39}$ The WHA, the plenary body of the wHO, has the power to adopt regulations concerning the prevention of international spread of disease.$^{40}$ Regulations are binding on all wHO members, except for those that have opted out. ${ }^{41}$ No state has opted out of the International Health Regulations, the most recent version of which was adopted in 2005 (IHR 2005), ${ }^{42}$ making the IH R 2005 one of the most universally accepted international agreements. ${ }^{43}$ The IHR 2005 are designed to be 'the key global instrument for protection against the international spread of disease. ${ }^{44}$ The IHR 2005 serve a dual purpose: to promote and protect the public health of all people while not unduly restricting international traffic and trade. ${ }^{45}$ The IHR 2005 attempt to balance the sovereignty of member states with obligations for international cooperation necessary to address public health risks.

The IHR 2005 are generally territorial in application and impose obligations on states regarding events within their territory regardless of the source of the event or the legal status of particular groups, such as refugees. Central to the IHR 2005 is the obligation of states to maintain minimum core capacities in their respective domestic health sectors to effectively detect, assess, report and respond to health threats occurring within their territory ${ }^{46}$ Minimum core capacities should allow states to respond quickly and adequately to

\footnotetext{
38 Constitution of the World Health Organization, 22 July 1946 ('WHO Constitution') art. 1.

39 Ibid., preamble.

$40 \quad$ Ibid., art. 21(a).

41 Ibid., art. 22.

42 IHR 2005 (n 25). The first version of the IHR was adopted in 1969 and substantially revised in 2005 after the SARS outbreak in 2002-2004.

43 wHo, 'States Parties to the International Health Regulations (2005)' <https://www.who .int/ihr/legal_issues/states_parties/en/>. Two states have entered reservations.

44 WHA, 'Revision of the International Health Regulations' (23 May 2005) WHA58.3, preamble.

$45 \quad$ IHR 2005 (n 25) art. 2.

$46 \quad$ Ibid., arts. 5, 6, 13, annex 1.
} 
health threats, such as outbreaks of contagious diseases. The onus to detect and respond to health threats lies on states and the wHo's role is limited to providing technical and other assistance to states on request. ${ }^{47}$ Annex 1 of IH R 2005 lists a series of detailed capacities that states must have established. However, failure to achieve such standards entails no consequence under the IH R $2005 .{ }^{48}$ There is no mandatory reporting process. Combined with the lack of effective dispute settlement mechanism under the IHR 2005 (see below), this means that compliance with the standard to which states are subject cannot be enforced either by member states or by the wHO. Both the IPPPR and the IH R 2005 Review Committee highlighted that the lack of state compliance with these obligations meant that many national health systems were underprepared for the pandemic. In 2016, only 42 states parties declared that they met core capacity requirements. ${ }^{49}$ While some states parties have simply not invested enough in their core capacities, others, particularly poorer developing countries, lack the resources to meet their obligations. ${ }^{50}$ The IPPPR and the IHR 2005 Review Committee identified the need for greater compliance by states and monitoring and enforcement as a key component of reform of the GHL regime to address pandemics in the future. ${ }^{51}$

In addition to obligations to achieve minimum core capacities, the IHR 2005 give the wHo Director-General the power to declare a public health emergency of international concern (PHEIC) when there is a risk of international spread and an international response is required. ${ }^{52}$ Since 2005, there have been six PHEIC declarations, all for the international spread of contagious diseases, including Ebola, swine flu and the Zika virus. ${ }^{53}$ On 30 January 2020 , the wHо Director-General declared the spread of Covid-19 to be a PHEIc. ${ }^{4}$ The declaration of a PHEIC enables the wHO to make non-binding temporary

47 See, for example, ibid., arts. $10(3), 13(3), 44$.

48 Giulio Bartolini, "The Failure of "Core Capacities" under the wHo International Health Regulations' (2O21) 7 O ICLQ 223, 237.

49 wHo, 'Report of the Review Committee on the Role of the International Health Regulations (2005) in the Ebola Outbreak and Response' (13 May 2016) A69/21, para. 21.

$50 \quad$ Ibid., para. 145 .

$51 \quad$ IPPPR (n 4) 50-51; IHR 2005 Review Committee (n 5), 52-54.

52 Ibid., art. 12.

53 See, for example, Adam Kamradt-Scott, 'WHO's to Blame?: The World Health Organization and the 2014 Ebola Outbreak in West Africa' (2016) 37 Third World Quarterly 401.

54 wHо, 'WHO Director-General's Statement on IHR Emergency Committee on Novel Coronavirus (2019-NCoV)' (3o January 2020) <https://www.who.int/director-general/ speeches/detail/who-director-general-s-statement-on-ihr-emergency-committee-on -novel-coronavirus-(2019-ncov)>. 
recommendations..$^{55}$ These recommendations are formulated by an Emergency Committee of experts convened by the wHo Director-General and address both states and the wHO. ${ }^{56}$ States may take measures that go beyond the temporary recommendations, but the wHO can ask states to reconsider measures that overly restrict international traffic. ${ }^{57}$

The wHO does not have a mandate to respond directly to a public health emergency occurring in one or more member states; the wHO is not a first responder but rather a network manager that coordinates, makes recommendations and offers technical support and assistance only with the consent of states. This too highlights the sovereign position of states under the IHR $2005{ }^{58}$ with states retaining control over the response to public health threats and being able to ignore or contradict a wHO temporary recommendation with no prospect of enforcement. The need to provide a clear mandate for WHO to be more proactive and have greater authority to lead a response to a public health emergency is another key recommendation of both the IPPPR and the IHR 2005 Review Committee. ${ }^{59}$ The IPPPR has also highlighted that the IHR 2005 are a conservative instrument designed to provide a series of requirements that must be met before action can be taken to respond to a public health emergency rather than providing for a prompt response to an emerging and fast-moving threat. ${ }^{60}$ The IHR 2005 also require actions to be taken on a consensual basis and provide no technical detail on the response, including obligations of other states to provide assistance or of the affected state to accept assistance. This can be contrasted with IDL, discussed below.

In terms of regime interaction, GHL addresses the interaction between international traffic and trade in the IHR 2005. Article 57, which addresses the relationship with other agreements, provides that 'States Parties recognize that the IHR and other relevant agreements should be interpreted so as to be compatible'. Moreover, the IH R 2005 'shall not affect the rights and obligations of any State Party deriving from other international agreements'. ${ }^{61}$ Yet there is no guidance as to how states parties are to arrive at a 'compatible' interpretation between agreements. The IHR 2005 interact with IHRL, requiring implementation to take place 'with full respect for the dignity, human rights and fundamental freedoms of persons' and be guided by the UN Charter and

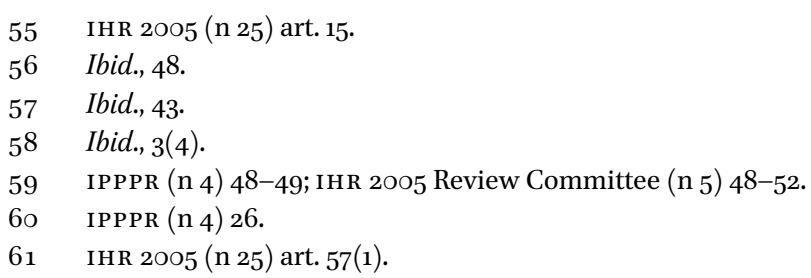


the wHo Constitution. ${ }^{62}$ In turn, the wHo Constitution recognises that the highest attainable standard of health is one of the fundamental rights of every human being without distinction of race, religion, political belief, economic or social condition. ${ }^{63}$ Article 2 states that two functions of the wHO are to (a) provide technical assistance and, in emergencies, necessary aid upon the request or acceptance of governments; and (b) provide or assist in providing upon the request of the UN, health services or facilities to special groups. As discussed in more detail below, these functions potentially interact with IDL and IRL on the provision of assistance in an emergency and/or to refugees in camps.

Under the wHO Constitution and the IH R 2005, the wHO is expected to cooperate and collaborate with international actors, including entering agreements with other international organisations. ${ }^{64}$ These include key institutional actors from other regimes, the UN (including UNHCR, UN Office for the Coordination of Humanitarian Affairs (OCHA) and potentially the UN human rights bodies) and the International Federation of Red Cross and Red Crescent Societies (IFRC). Cooperation between WHO and UNHCR is based on a Memorandum of Understanding (MoU) between the two organisations adopted in May 2020, which replaced and revised an earlier agreement. ${ }^{65}$ The MoU sets out the principles of partnership in Part III as well as specific responsibilities of each of the parties in Part IV. ${ }^{66}$ The MoU recognises the mandate of UNHCR for refugees and stateless persons and the likelihood that the host state will require assistance in providing adequate health care both for refugees and the broader population. The MoU is to be supplemented by country-specific arrangements, which are generally not publicly available. The WHO-UNHCR MoU recognises the interaction between GHL and IRL at an institutional level, making the connection that ensuring the health of refugees 'is fundamental to protecting and promoting their human rights' and the need for the organisations to work

$62 \quad$ Ibid., art. 3(1)-(2).

63 wно Constitution (n 38$)$ preamble.

64 IHR 2005 (n 25) art. 14(1); WHO Constitution (n 38) arts. 70-71.

65 Memorandum of Understanding between the United Nations High Commissioner for Refugees and the World Health Organization, 21 May 2020 ('UNHCR-WHO MoU'). The MoU clarifies what technical support the WHO will provide to UNHCR and Ministries of Health to enable extension of health services to refugees.

66 Other examples of treaties providing a legal framework for cooperation between international organisations include MoUs between UNHCR and the World Food Programme (WFP), Food and Agriculture Organization (FAO), UN Fund for Population Activities (UNFPA), the UN Children's Agency and the International Labor Organization (ILO). See UNHCR, 'MoUs and LoUs with UN Agencies and NGOs' <https://emergency.unhcr.org/ entry/41967/mous-and-lous-with-un-agencies-and-ngos>. 
together 'to reinforce the rights of refugees'. ${ }^{67}$ Yet, there is no detail as to how this interaction between GHL and IRL is to be achieved in practice. Particularly given the weakness of dispute settlement options, this suggests that any inconsistency or incompatibility between the regimes and the institutional actors will likely be resolved informally through practice and discussion rather than the adoption of formal rules or guidance on interpretation.

Public health measures adopted by states to control the pandemic have had a significant impact on the enjoyment of fundamental rights of affected populations. ${ }^{68}$ Yet despite the WHO's recognition of the human rights dimension of its mandate, concern for human rights has not been a key feature of the formal response to COVID-19, particularly when compared to the concern for minimising the impact on international traffic and trade. ${ }^{69}$ This failure is illustrated clearly by the temporary recommendations issued. As of May 2021, the Emergency Committee has issued six temporary recommendations concerning the response to the CoviD-19 pandemic. ${ }^{70}$ These recommendations typically call for the wHо to coordinate the global response and to support states where possible. States are advised to cooperate and maintain essential health services. The recommendations are formulated in general terms and lack specific advice; importantly, the recommendations do not require any specific public health and social measures (PHSM) to be taken (or not taken). For example, they include calls to avoid politicisation of pandemic response and call for equitable access to tests, personal protective equipment and vaccines. While the temporary recommendations attempt to balance the protection of public health and not unduly restricting international traffic, there is minimal attention to vulnerable groups, such as refugees, and no expectation that states will balance the need for public health measures against the impact on rights. This is despite the IHR 2005 specifying criteria for making temporary recommendations that include: first, that the PHSM 'are no more intrusive to persons than other reasonably available alternatives that would achieve the appropriate level of health protection'; and second, 'relevant international standards and instruments', ${ }^{71}$ which we suggest includes both IRL and IHRL. The IHR 2005 thus enable, in fact require, the Emergency Committee to have regard to these factors when deciding on temporary recommendations.

\footnotetext{
67 UNHCR-WHO MoU (n 65) arts. 5-6.

68 Judith Bueno de Mesquita, Anuj Kapilashrami and Benjamin Mason Meier, 'Human Rights Dimensions of the COVID-19 Pandemic, Background Paper 11' (IPPPR 2021) 16.

$69 \quad$ IHR 2005 Review Committee (n 12) 44, para. 98.

70 World Health Organization, 'COVID-19 IHR Emergency Committee' <https://www.who .int/groups/covid-19-ihr-emergency-committee>. 
One role of the wHO in a public health emergency is to issue technical guidance to states, ${ }^{72}$ with wHO reportedly issuing a considerable volume of guidance during the pandemic. ${ }^{73}$ On 16 April 202O, the WHO issued interim guidance recognising the need for states to assess the broader social and economic impact of PHSM, particularly lockdown or shutdown measures. ${ }^{74}$ The guidance highlighted that such measures should be based on a risk assessment driven by scientific evidence and take into account other critical factors, including human rights. This was followed by a three-page public document issued by wHO on 21 April 2020 emphasising the comment of the Director-General that '[a]ll countries must strike a fine balance between protecting health, minimising economic and social disruption, and respecting human rights'.75 The document makes clear that there is a link between integrating human rights concerns into responses to COVID-19 and the effectiveness of such measures in addressing public health concerns. Relevantly, the document highlights the need for states to provide additional support for groups such as refugees, who are at greater risk 'depending on their living conditions, financial instability and lack of specific safeguards impacting their risk of infection. ${ }^{76}$ WHO issued further updated interim guidance in November 2020 reiterating that, while a decision to introduce or vary PHSM should be driven by a situational assessment of transmission risks and capacity of the health system, it must also consider the effects such measures have on the general welfare of societies and individuals, including human rights. ${ }^{77}$ The updated guidance provided more detailed advice to states as to how to assess PHSM, providing several guiding principles for decision-makers. Relevant to our context is the strong emphasis on protecting vulnerable communities, including refugees: 'it is critical to safeguard vulnerable and disadvantaged populations by implementing specific measures to support them. ${ }^{78}$ The updated interim guidance is phrased more in terms of epidemiological factors, but by recommending specific

$72 \quad$ Ibid., art. 13(3)-(4).

73 The IPPPR identified almost 900 recommendations published by wн between January and November of 2020. See IPPPR, 'Second Report on Progress' (January 2021) 18.

74 WHO, 'Considerations in adjusting public health and social measures in the context of COVID-19 - Interim Guidance' (16 April 2020) wHo/2019-nCoV/Adjusting_PH _measures/2020.1. wHO, 'Addressing Human Rights as Key to the COVID-19 Response' (21 April 2020) wHO/2O19-nCoV/sRH/Rights/2O2O.1.

$76 \quad$ Ibid.

77 WHо, 'Considerations for implementing and adjusting public health and social measures in the context of COVID-19 - Interim Guidance' (4 November 2020) wHo/2019-nCoV/ Adjusting_PH_measures/2020.2.

$78 \quad$ Ibid., 3 . 
support measures for refugees it arguably requires states to offer a higher level of protection and assistance to refugees as vulnerable groups than that required by IRL, which only requires the same level of assistance as that given to the general population. Interestingly, despite the reference to the need to consider the impact of PHSM on human rights, the guidance and the public statement by the wHO do not refer to the criteria that IHRL would apply to assess the lawfulness of PHSM taken to protect the right to health, as discussed further below. This was an obvious point of regime interaction and an opportunity to address the application of potentially different standards that the wHO did not act upon.

As noted above, the wHO does not enforcestate obligations, including whether the PHSM adopted by states in response to COVID-19 are justified or necessary, whether as a matter of public health or in relation to states' human rights obligations. States parties are responsible for the PHSM adopted in accordance with national law and their international obligations and can go beyond measures recommended by the wHO. The only limits are that health measures must be taken 'without delay' and 'applied in a transparent and nondiscriminatory manner'79 and should not be 'more restrictive of international traffic and not more invasive or intrusive to persons than reasonably available alternatives' ${ }^{80}$ As a result, states have been largely left to make this assessment individually and have come to varying outcomes. Where some states determined that certain measures were too invasive of individual freedoms, others concluded that measures were permissible. ${ }^{81}$ Even where the limits under the IHR 2005 are exceeded, the WHO has no power to review or to compel a state party to revoke any PHSM. ${ }^{82}$ Despite the extensive number and scope of PHSM adopted by states parties during COVID-19, the IHR 2005 Review Committee found that wHO had not queried any PHSM adopted. ${ }^{83}$ The committee called for a clearer role for wHO in identifying criteria for assessing PHSM. ${ }^{84}$ This, we

79 IHR 2005 (n 25) art. 42.

8 o Ibid., art. $17(\mathrm{~d})$.

81 See, for example, Sarah Joseph, 'International Human Rights Law and the Response to the COVID-19 Pandemic' (2020) 11 Journal of International Humanitarian Legal Studies 249, 254, 258. Joseph argues that Sweden's relaxed approach to controlling the pandemic violated the rights to life and health. However, China's strict lockdowns may have violated the absolute right to freedom from inhuman and degrading treatment, for example, where welding doors shut prevented escape from family violence, alongside violations of other rights where restrictions are permitted for public health reasons.

82 See IHR 2005 ( $\mathrm{n}_{25}$ ) art. 43, which limits WHO's role to one of drawing attention to the measure and consulting the state.

83 IHR 2005 Review Committee (n 5) 41-42.

84 Ibid., 45 . 
argue, is an opportunity for, and requires, recognition and acceptance of the interaction between GHL and other regimes, including IRL and IHRL.

GHL does not currently have any mechanisms with a mandate to address the relationship between GHL and other regimes and rules. Like IRL, there is no mechanism allowing for individual complaints arising from the GHL regime or for state reporting. The wHO Constitution provides that any dispute between states concerning the interpretation or application of the Constitution that is not settled by negotiation or by the WHA shall be referred to the ICJ unless parties agree to other means of dispute settlement. ${ }^{85}$ To date, no disputes have been referred to the WHO or the ICJ. The wHO may request an advisory opinion from the ICJ but has only done so successfully once concerning a dispute between the WHO and Egypt on the transfer of the seat of the Regional Office to another country. ${ }^{86}$ The IHR 2005 dispute settlement mechanism provides that disputes between a state and the wHO should be referred to the WHA. ${ }^{87}$ This mechanism is weak and has never been used. ${ }^{88}$ The WHO-UNHCR MoU contains a dispute settlement provision that provides for a political settlement, committing the organisations to resolve disputes amicably and, where this is not possible within sixty days, to refer to the UN High Commissioner for Refugees and Director-General of the wHO for final resolution. ${ }^{89}$ Public criticism of the WHO or withholding of membership dues are the main options for states that dispute wHO actions such as the Director-General's decision to recommend temporary measures. ${ }^{90}$

Nonetheless, there are some other potential internal options. As noted above, at least two mechanisms have been established to review the wHO response to COVID-19. Both reviews have recognised the failure of the IHR 2005 to respond

85 who Constitution $\left(\mathrm{n}_{3} 8\right)$ art. 75 .

86 ICJ, Interpretation of the Agreement of 25 March 1951 between the WHO and Egypt (Advisory Opinion) [1980] ICJ Rep 73. The wHO did also request an advisory opinion on the legality of the use of nuclear weapons, but the ICJ held that this was not 'on any legal question arising within the competence of the Organization'. Legality of the Use by a State of Nuclear Weapons in Armed Conflict (Advisory Opinion) [1996] ICJ Rep 66, 84, para. 31.

$87 \quad$ IHR 2005 (n 25) art. 56 (5).

88 A dispute between states that cannot be resolved through negotiation can be referred to the wно Director-General. If it is still unresolved, it can be referred to arbitration under the Permanent Court of Arbitration Rules, see IHR 2005 (n 25) art. 56(1)-(3). A savings clause enables states to pursue other dispute settlement mechanisms via other international organisations or treaties, see IHR 2005 art. 56(4). See further Giulio Bartolini, 'The Failure of "Core Capacities" under the wHo International Health Regulations' (2021) 70 ICLQ 223, 25 O.

$89 \quad$ UNHCR-WHO MoU (n 65) art. 32.

9o Withholding membership dues is a breach of treaty obligation on the part of the WHO member state. 
to the pandemic and the challenges of compliance and accountability. Both reviews have recognised the impact of COVID-19 and public health measures on human rights, particularly of vulnerable populations including refugees, yet neither has considered in any detail the interaction between these regimes. Both reviews have endorsed a periodic reporting mechanism, based on the human rights monitoring bodies. ${ }^{91}$ At present, the focus is on states reporting on the capacity of the national health system and emergency planning, given this was a critical failing in the ability to respond to COVID-19. Yet monitoring and reporting is also an opportunity for reporting emergency preparedness and for transparency after PHSM have been. Reporting could also assist in building an evidence base to guide which PHSM are taken in future, drawing on experience from COVID-19, including the impact of various measures and how PHSM can be better balanced against human rights. Importantly, both reviews supported the urgent adoption of a framework convention on pandemic preparedness and response, which we suggest should consider the interaction between GHL and other regimes as well as the interaction between the IHR 2005 and the proposed convention. ${ }^{92}$ This could be through the provisions of the convention itself or, more likely, in the form of a protocol. Moreover, the related proposal for a dispute settlement mechanism for GHL would provide another potential forum for considering issues of regime interaction.

\subsection{International Disaster Law}

International disaster law aims to regulate disaster risk reduction and the international response to disasters to reduce human vulnerability. ${ }^{93}$ The IDL regime is comparatively underdeveloped, both in terms of applicable principles and rules and in terms of international institutions. IDL lacks a universal, comprehensive, 'flagship' treaty and only a few binding instruments outline a legal framework for international disaster response. Instead, the IDL regime relies mostly on non-binding instruments and national laws. ${ }^{94}$ IDL also lacks well-established international institutions. While some international actors

$91 \quad$ IPPPR (n 4) 51; IHR 2005 Review Committee (n 5) 53-54.

92 IPPPR (n 4) 47; IHR 2005 Review Committee (n 5 ) 52.

93 David Fisher, 'International Disaster Relief: A Growing Regulatory Dilemma' (2007) 101 Proceedings of the ASIL Annual Meeting 114, 114. Even now, its existence as a regime is contested.

94 Ibid.; Sandesh Sivakumaran, 'Techniques in International Law-Making: Extrapolation, Analogy, Form and the Emergence of an International Law of Disaster Relief' (2017) 28(4) European Journal of International Law 1097; Claire Clement, 'International Disaster Response Laws, Rules, and Principles: A Pragmatic Approach to Strengthening International Disaster Response Mechanisms' in David Caron, Michael Kelly and Anastasia Telesetksy (eds), The International Law of Disaster Relief (CUP 2014). 
support disaster response missions, such as the OCHA, institutional influence in IDL is lower when compared to the other regimes studied here. There is no authoritative institution that has a mandate to lead the international response to a disaster or to develop the regime, although the IFRC plays a similar role in relation to IDL as the International Committee of the Red Cross does in relation to international humanitarian law. IDL instruments are territorial in application with a focus on the affected state, although they also seek to impose obligations on other states and assisting actors; however, as most of the instruments are themselves non-binding, so too are these obligations. ${ }^{95}$

In the absence of IDL treaties, we focus on the ILC's Draft Articles on the Protection of Persons in the Event of Disasters (Draft Articles). ${ }^{96}$ It remains unclear whether the Draft Articles will eventually be adopted as a treaty or remain in draft article form. ${ }^{97}$ They may come to be considered as customary international law, like the ILC Articles on State Responsibility; however, given that states cannot agree to adopt them as a treaty, this seems unlikely. The Draft Articles do not specify the events that can be considered 'disasters' but define disaster as 'a calamitous event or series of events resulting in widespread loss of life, great human suffering and distress, mass displacement, or large-scale material or environmental damage, thereby seriously disrupting the functioning of society.' ${ }^{98}$ The effects, rather than the cause, are relevant in determining whether a disaster exists. ${ }^{99}$ Considering the broad definition and the declaration of the CoviD-19 outbreak as a pandemic with significant impact worldwide, the pandemic qualifies as a disaster for the purpose

95 Binding instruments include the Tampere Convention on the Provision of Telecommunications Resources for Disaster Mitigation and Relief Operations, 8 January 2005; the ASEAN Agreement on Disaster Management and Emergency Response, 26 July 2005, and numerous bilateral disaster assistance treaties.

96 ILC, 'Draft Articles on the Protection of persons in the event of disasters' (27 May 2016) $\mathrm{A} / \mathrm{CN}_{4} / \mathrm{L} 871$ ('Draft Articles'). The other main instrument is the IF RC, 'Guidelines for the Domestic Facilitation and Regulation of International Disaster Relief and Initial Recovery Assistance' (2007). The IDRL Guidelines do not directly address the rights of affected persons, inasmuch as they are primarily of a technical nature, focussed on assisting states to avoid common regulatory problems in international operations, such as entry of relief personnel and customs clearance.

UNGA Res 71/141 (13 December 2016) UN Doc A/Res/71/141; UNGA Res 73/209 (20 December 2018) UN Doc A/REs/73/209.

98 Draft Articles (n 96) art. 3(a).

99 Guilio Bartolini, 'A Taxonomy of Disasters in International Law' in Flavia Zorzi Giustiniani and others (eds), Routledge Handbook of Human Rights and Disasters (Routledge 2018) 10,15 . 
of applying the Draft Articles. ${ }^{100}$ Despite this, until recently, it did not appear that IDL had a role to play in the response to CovID-19. This might be as GHL is a more specific regime that does not conflict with or rely on IDL for interpretation. Alternatively, IDL may appear most relevant to situations like a fire, flood or cyclone in a refugee camp. However, the extent of offers of international assistance to India in response to the dramatic rise in coviD-19 cases in April 2021 demonstrates that IDL remains potentially relevant. ${ }^{101}$ The two wHO reviews discussed above also highlighted the lack of detail in the IHR 2005 for response to a global public health emergency of the scale of Covid-19, including the absence of any formal mandate for wHO to take a more active role in leading and coordinating the response, including acting as a responder itself where appropriate. ${ }^{102}$ Moreover, as currently drafted, the IHR 2005 do not require states to request or accept assistance from the wHO or any other state or organisation, even where national capacity is overwhelmed, or to justify a refusal to accept assistance. In addition, the IHR 2005 do not provide sufficient detail as to how such assistance should best be facilitated, particularly in the light of national restrictions on travel and, in many cases, on exporting personal protective equipment and, more recently, vaccines. IDL includes treaties that aim to facilitate swift processing of goods and equipment for disaster relief, and, therefore, there is clear potential for interaction between IDL and GHL. ${ }^{103}$ As discussed below, IDL also engages with IH RL directly and to a lesser extent with IRL.

The Draft Articles do not specifically refer to a pandemic or health emergency but set out clear provisions concerning the provision of assistance to disaster victims. The Draft Articles link directly to IHRL, emphasising the importance of human dignity, human rights and humanitarian principles in disaster response. ${ }^{104}$ Importantly, the Draft Articles recognise that the affected

100 Pouria Askary and Farzad Fallah, "The Right to International Solidarity and Humanitarian Assistance in the Era of COVID-19 Pandemic' (2020) 11 Journal of International Humanitarian Legal Studies 193, 196-197; Alp Ozturk, 'COVID-19: Just Disastrous or the Disaster Itself? Applying the ILC Articles on the Protection of Persons in the Event of Disasters to the Covid-19 Outbreak' (ASIL Insights 2020) <https://www.asil.org/insights/ volume/24/issue/6/covid-19-just-disastrous-or-disaster-itself-applying-ilc-articles >.

101 Jack Hunter, 'India Covid aid: Is emergency relief reaching those in need?' BBC News (6 May 2021) <https://www.bbc.com/news/world-asia-india-56999104>.

102 IPPPR (n 4) 48-49; IHR Review Committee (n 5 ) 48, 52.

103 See, for example, UN OCHA, 'UN Model Agreement concerning measures to expedite the import, export, and transit of relief consignments and possessions of relief personnel in the event of disasters and emergencies' < https://www.unocha.org/sites/dms/Documents/ Model_en_2011.pdf>.

104 Draft Articles (n 96) arts. 4-6. 
State has the duty to ensure the protection of persons and provision of disaster relief assistance in its territory and has the primary role in managing disaster relief. ${ }^{105}$ This provision reinforces state sovereignty, but seeks to interpret sovereignty as responsibility, and reflects the principle that the territorial state is usually best placed to assess how to respond to a disaster. The Draft Articles do not address the specific situation of a disaster occurring in a refugee camp, but the territorial state is primarily responsible for assisting disaster victims. ${ }^{106}$ As with IRL, this places the burden on the host state in a refugee context.

The Draft Articles address regime interaction, although in a limited way. Article 18(2) expressly precludes the application of the Draft Articles 'to the extent that the response to a disaster is governed by the rules of international humanitarian law', recognising that that regime is lex specialis. ${ }^{107}$ Article 18(1) is a 'without prejudice' clause, which seeks to clarify the ways the Draft Articles intersect with other rules. However, the provision only makes clear that other rules of international law continue to apply in a disaster, without clarifying how different rules that might address the same subject matter should be applied. The commentary mentions 'more specific rules' but does not address GHL, IRL or IHRL. ${ }^{108}$ Furthermore, the Draft Articles do not contain a dispute settlement clause, nor do they establish an institution to administer the regime or a monitoring or enforcement mechanism. There is little formal guidance as to how rules of IDL intersect with those of other regimes.

Assistance should be distributed based on need, in accordance with accepted principles of humanitarian assistance, and without discrimination, including as to the legal status of beneficiaries. ${ }^{109}$ This goes further than similar provisions in IRL and would support the argument made in relation to GHL that a

\footnotetext{
105 Ibid., art. 10.

106 Ibid., art. $10(2)$. Art 6 states that response to disasters shall take into account 'the needs of the most vulnerable', which is likely to include refugees.

107 The commentaries also make clear that an armed conflict of itself does not constitute a disaster for the purpose of triggering the application of the Draft Articles. See ILC, 'Draft articles on the protection of persons in the event of disasters, with commentaries' (2016) A/71/10 under art. 3, para. 10.

108 Ibid., under art. 18, para. 4.

109 The aim of humanitarian aid is 'to bring assistance without discrimination [...] to prevent and alleviate human suffering wherever it may be found. [...] It makes no discrimination as to nationality, race, religious beliefs, class or political opinions. It endeavours only to relieve suffering, giving priority to the most urgent cases of distress' and it is 'given without distinction to all in need'. See ICJ, Military and Paramilitary Activities in and against Nicaragua (Nicaragua v. United States of America) (Merits) [1986] ICJ Rep 14, paras. $242-243$.
} 
state may be required to provide more assistance to refugees than to the general population if required due to refugees' special vulnerability and need. Like GHL and IRL, IDL recognises that the territorial state may be overwhelmed by the challenge of providing assistance and that other states and actors should cooperate and share this burden. IDL does this in two ways. First, IDL goes beyond other regimes and creates an obligation for states to cooperate among themselves and with the UN, the International Red Cross and Red Crescent Movement and other assisting actors to respond to a disaster. ${ }^{110}$ The duty of the affected state must be read in the context of this obligation of other actors to cooperate. Second, IDL recognises a limited duty on the affected state to seek assistance where 'a disaster manifestly exceeds its national response capacity', which is based on IHRL (including the right to health and right to life) and customary international law. ${ }^{111}$ Together, these provisions suggest that the obligation of the affected state to assist persons affected by disaster is only up to the level of national capacity, which is similar to that found in IRL (see above) and IHRL (see below). However, when that capacity is exceeded, the affected state must seek assistance and other states and organisations have a responsibility to assist. The IHR 2005 Review Committee suggests a similar obligation on states whose national health capacity is overwhelmed, recommending that the WHO and other states should be able to offer to assist a state and, where national capacity is overwhelmed, the state must justify any refusal to accept assistance. ${ }^{112}$ Both the IHR 2005 Review Committee and the IPPPR called for more detailed guidance on collaboration and technical provisions on response to pandemics, in the form of a new legal instrument on pandemic preparedness and response. ${ }^{113}$ IDL may provide a basis for developing the new instrument.

\subsection{International Human Rights Law}

IHRL potentially provides a useful framework as the need to balance rights, as shown by measures to respond to COVID-19, is inherent within this regime. For present purposes, we focus on the right to health under the International Covenant on Economic, Social and Cultural Rights (ICESCR). ${ }^{114}$ While other international human rights instruments may also apply, the right to health is the most relevant in the CovID-19 pandemic.

\footnotetext{
110 Draft Articles (n 96) art. 7. Art. 8 specifies the forms such cooperation might take.

111 ILC (n 107) under art. 11, para. 3.

112 IHR 2005 Review Committee ( $\left.\mathrm{n}_{5}\right) 5^{2}$.

113 Ibid., 47, $5^{2}$.

114 International Covenant on Economic, Social and Cultural Rights, 19 December 1966 ('ICESCR').
} 
The ICESCR applies in all contexts and extends a range of rights, including the right to health. While not permitting derogation, it incorporates limits in the rights themselves and article 4 permits the state to impose limits on the enjoyment of rights 'as may be compatible with the nature of these rights and solely for the purpose of promoting the general welfare in a democratic society'. The ICESCR includes a non-discrimination provision, so rights must be respected regardless of legal status in the country. ${ }^{115}$ Article 12 addresses the right to health and the host state is responsible for ensuring the right to health of everyone within its territory, including refugees. In particular, article 12 includes the obligation to take steps necessary for the realisation of '(c) The prevention, treatment and control of epidemic, endemic, occupational and other diseases'. However, while this obligation initially appears stringent, it is limited in several respects. First, unlike the IHR 2005, article 12 does not set out what the required health standards or actions are, making the provision a less definite standard than that under Annex 1 of the IHR 2005. Second, the obligation is limited to the progressive realisation of the right to health and is constrained by the level of development and resources available to national health authorities. ${ }^{116}$ The right to health is in this sense an aspiration, rather than an obligation of result. ${ }^{117}$ Third, the ICESCR recognises the role of other states and international actors in assisting the territorial state to achieve the realisation of the right to health, which is consistent with wHO's mandate in this area. ${ }^{118}$ Finally, the obligation to realise the right to health is linked to the extent that achieving the right to health and controlling the pandemic can impact other rights, both within the ICESCR and in other human rights instruments, although article 12 does not address how the right to health should be balanced against other rights in the context of a global pandemic. In particular, the application of article 4, which allows the state to impose limits on the enjoyment of the right, needs to be addressed.

The ICESCR does not contain specific rules on interaction with other regimes. However, unlike the other regimes explored in this article, the ICESCR has a treaty monitoring body - the Committee on Economic, Social and Cultural Rights (CESCR) - that seeks to clarify how the rights in each instrument should be applied, including in the context of coviD-19. This is an important mechanism for balancing rights within a regime and for addressing

\footnotetext{
115 Ibid., art. 2(2).

116 CESCR, 'General Comment 14: The Right to the Highest Attainable Standard of Health (article 12)' (11 August 2000) UN Doc E/C.12/2000/4, para. 2(a).

117 ICESCR (n 114) art. 2(3): 'Developing countries (...) may determine to what extent they would guarantee economic rights (...) to non-nationals'.

118 Ibid., art. 2.
} 
regime interaction. The CESCR's General Comment 14 on the right to health expressly recognises the role of the WHO and its programs as one approach to the realisation of the right to health, although it acknowledges that the right to health under article 12 embraces a range of socio-economic factors and is wider than the definition of health in the wHo Constitution. ${ }^{119}$ The Comment recognises the aspirational element of the right to health for many states and provides guidance as to the actions that should be taken by states. ${ }^{120}$ It also intersects with and extends beyond IRL when it states that the right to health is to be enjoyed by vulnerable populations (which would include refugees) without discrimination and who must have equality of access. ${ }^{121}$ However, General Comment 14 only briefly addresses article 12(2)(c). It mentions the need for emergency care and disaster relief and humanitarian assistance but does not refer directly to these regimes or their standards and obligations for states. Similarly, the Comment lists several categories of vulnerable populations but does not include refugees specifically or link to IRL.

General Comment 14 does provide some guidance in the potential application of article 4 and the use of public health as a justification for restricting other rights, as states bear the burden of justifying interference with other rights and that any restrictions imposed must be in accordance with the law (including IHRL). The Comment also provides that states parties 'should recognize the essential role of international cooperation and comply with their commitment to take joint and several actions to achieve the full realization of the right to health.'.122 States parties must ensure that the right to health is to be given due attention in international agreements and is not adversely impacted by other instruments. ${ }^{123}$ Importantly, the Comment expressly links to the UN Charter and resolutions of the General Assembly and wHA to highlight the responsibility of states parties to cooperate in providing disaster relief and humanitarian assistance in times of emergency, including to refugees, based on the needs of the most vulnerable groups and the collective responsibility for diseases that cross international borders. ${ }^{124}$ While this appears to integrate the right to health with other regimes, such as GHL and IDL, this link is not made explicit or considered in any detail.

General Comment 14 sets out core obligations from which there can be no derogation. This includes access to health care on a non-discriminatory basis,

\footnotetext{
119 CESCR (n 116) paras. $1,4$.

120 Ibid., para. $30 \mathrm{ff}$.

121 Ibid., para. $18 \mathrm{ff}$.

122 Ibid., para. $3^{8}$.

123 Ibid., para. 39.

124 Ibid., para. 40.
} 
especially for vulnerable groups, and adopting and implementing a public health strategy 'addressing the health concerns of the whole population'.125 This also supports the argument made above, that the obligation to assist refugees may be higher than that found in IRL, which is limited to the same level of assistance as the general population and requires greater efforts to safeguard the health of vulnerable populations such as refugees. Non-core obligations are also relevant here, namely, providing immunisation and taking 'measures to prevent, treat and control epidemic and endemic diseases.' ${ }^{126}$ However, these standards are not at the level of detail seen in Annex 1 to the IHR 2005. General Comment 14 sets out in general terms what would constitute violations of both core and non-core obligations, distinguishing between unwillingness and inability to comply with requirements. ${ }^{127}$ So there is no violation of article 12(c) where 'resource constraints render it impossible for a State to comply fully with its Covenant obligations' and provided that 'every effort has nevertheless been made to use all available resources at its disposal' to do so. ${ }^{128}$ This is an important limitation on the potential responsibility of state parties in the context of Covid-19.

The Comment also recognises state sovereignty, noting that the feasible measures to give effect to the right will vary from state to state, ${ }^{129}$ although it calls on states to avail themselves of the technical assistance and cooperation of WHO and to use its expertise regarding benchmarks and applicable standards. ${ }^{130}$ This would include the wHO interim guidance on considerations for states in adopting or modifying PHSM discussed above. ${ }^{131}$

The CESCR has made two statements specifically concerning COVID-19: a statement on pandemic and economic, social and cultural rights and a statement addressing equality of access to vaccines. ${ }^{132}$ The first statement notes that the pandemic threatened to overwhelm public health systems and has 'profoundly negative impacts' on the enjoyment of rights, especially the right to health of the most vulnerable groups, and stresses that states must act

\footnotetext{
125 Ibid., para. 43 .

126 Ibid., paras. 43-44.

127 Ibid., para. 47.

128 Ibid., para. 47.

129 Ibid., para. 53.

130 Ibid., para. 63 .

131 Wно (n 75); wно (n 77).

132 CESCR, 'Statement on the coronavirus disease (COVID-19) pandemic and economic, social and cultural rights' (17 April 2020) UN Doc E/C.12/2020/1; CESCR, 'Statement on universal and equitable access to vaccines for the coronavirus disease (COVID-19)' (27 November 202O) UN Doc E/C.12/2020/2.
} 
within a human rights framework to mitigate these impacts. ${ }^{133}$ The statement reiterates that, while the realisation of the right to health and other rights is not based on nationality, refugee camps are recognised as challenging environments and refugees as particularly vulnerable populations. ${ }^{134}$ It recommends that the "[a]llocation of resources should prioritize the special needs of these groups. ${ }^{135}$ The statement also emphasises the need for international assistance and cooperation ${ }^{136}$ and the extraterritorial obligations of states regarding global efforts to combat Covid-19. ${ }^{137}$ However, the statement does not link expressly to any wHO standards. The statement on access to vaccines reiterates the obligation not to discriminate and to determine access to vaccines based on public health grounds, which may require prioritising those who are most exposed and vulnerable, including refugees and displaced persons..$^{138}$ It also emphasises the obligations on states to cooperate internationally and assist in guaranteeing universal and equitable access to vaccines globally. ${ }^{139}$ As with General Comment 14, while these two statements clearly recognise the important role of the WHO in the realisation of the right to health during a pandemic, the CESCR does not consider regime interaction in detail or interpret article 12 (and other rights) consistently with the requirements under IHR 2005 .

Other human rights institutions have also responded to Covid-19. For example, the Office of the UN High Commissioner for Human Rights (OHCHR) issued guidance emphasising 'human rights at the heart of response', addressing the human rights of migrants ${ }^{140}$ and the limits to emergency measures. ${ }^{141}$ This guidance recognises that those in refugee camps are particularly vulnerable and reaffirms the principle of non-discrimination. ${ }^{142}$ The guidance does not provide any detail on how to reconcile different regimes in practice. While

\footnotetext{
133 CESCR, 'Statement on the coronavirus disease (COVID-19) pandemic and economic, social and cultural rights' (n 132) para. 2.

134 Ibid., para. 9 .

135 Ibid., para. 14.

136 Ibid., para. 19.

137 Ibid., para. 20.

138 CESCR, 'Statement on universal and equitable access to vaccines for the coronavirus disease (COVID-19)' (n 132) para. 5 .

139 Ibid., para. 9.

140 OHCHR, 'COVID-19 and the Human Rights of Migrants: Guidance' (7 April 2020) <https:// www.ohchr.org/Documents/Issues/Migration/OHCHRGuidance_COVID19_Migrants .pdf $>$.

141 OHCHR, 'Emergency measures and COVID-19: Guidance' (27 April 2020) <https://www .ohchr.org/Documents/Events/EmergencyMeasures_COVID19.pdf>.

142 OHCHR (n 140) 1.
} 
the comments and guidance of treaty monitoring bodies and other human rights actors recognise refugees, stateless persons, or those in camps as particularly vulnerable and the role and expertise of the wHO in the context of the right to health, there is little detailed guidance as to how various actors, including UNHCR, WHO and the host state, are to realise and protect rights in such contexts.

IHRL may offer greater potential than other regimes for analysis of regime interaction by dispute settlement bodies. In principle, IHRL articulates rights on an individual basis and has a stronger enforcement regime that allows individual-based complaints mechanisms and, in some regions at least, access to judicial settlement. The more lenient standard that applies under the ICESCR compared with the obligation to develop core capacities under the IHR 2005 could be enforced if an individual were to take a communication to the CESCR. However, this could only happen if the relevant state was party to the Optional Protocol to the ICESCR. ${ }^{143}$ Even where host states are party to the relevant treaties, individual refugees are unlikely to have access to the legal advice and assistance to take such claims, whether at domestic, regional or international levels. Most non-refoulement complaints to human rights treaty bodies are taken against developed country resettlement states as a final appeal from the rejection of an asylum application and it is difficult to identify complaints brought against states providing de facto refuge in the developing world. ${ }^{144} \mathrm{~A}$ further limitation in the IHRL regime is that neither wHO nor UNHCR is party to these instruments, nor are they directly responsible for ensuring these rights. Nor is it clear that a 'victim' of a rights violation by either organisation could access the UN human rights treaty body mechanisms. As discussed above, there is limited prospect for using the dispute settlement procedure under the IHR 2005 for a failure to meet the standard for the right to health. While the IHR 2005 provide for alternative dispute settlement under other treaties in the case of disputes between states, ${ }^{145}$ it is difficult to imagine a state taking a dispute to CESCR over another state's treatment of refugees within its territory based on an argument that the latter had failed to meet its IH R 2005 obligations to develop its core capacities.

The wHO reviews highlight the importance of human rights in the response to COVID-19 and in future pandemics. The IPPPR commissioned an expert

143 Optional Protocol to the International Covenant on Economic, Social and Cultural Rights, 10 December 2008.

144 Andrew Byrnes, 'The Committee against Torture and the Subcommittee on the Prevention of Torture' in Frédéric Mégret and Philip Alston (eds), The United Nations and Human Rights: A Critical Appraisal (ouP 2020 ${ }^{2}$ ) 477, 500.

145 IHR 2005 (n 25) art. 56(4). 
briefing paper that examined the human rights dimensions of the pandemic, ${ }^{146}$ set out the relevant human rights framework and made recommendations to strengthen the connection between IHRL and GHL, including a new suggestion that wHO should be able to report on states' compliance with the right to health as part of the human rights periodic review process. ${ }^{147}$ Yet the IPPPR did not incorporate those recommendations into its final report. Similarly, the IH R 2005 Review Committee 'sought to examine the extent to which the human rights provisions in the IHR have been followed in the response to COVID19.'148 Noting that there was no time for a full analysis, the panel 'deliberated at length about areas for future analysis concerning protecting human rights during emergencies' but included no recommendations in relation to interaction with human rights in the report. ${ }^{149}$ This, we argue, shows a clear need for closer consideration of regime interaction between GHL and other regimes as part of the review of the legal framework following COVID-19.

\section{What Does This Tell Us about Regime Interaction in Humanitarian Emergencies?}

As set out in section 2, the ILC Study Group identified two general types of relationships between regimes: relationships of interpretation and relationships of conflict. We have looked at four regimes - IRL, GHL, IDL and IHRL - which apply in refugee camps during the COVID-19 pandemic. Each of these regimes is specialised in the sense that it regulates a certain problem area. Yet, all aim to protect humans, human rights, and human dignity and link directly to the UN Charter and its principles and purposes. IRL, GHL and IDL all expressly refer to or incorporate IHRL. Excepting IH RL, the regimes are 'emergency-focused', although they recognise the need for long-term solutions and actions and in the case of IDL, disaster risk reduction and preparedness. All apply primarily on a territorial basis (in terms of obligations) while recognising that the problem to be addressed is not limited to one state but requires international collaboration and burden sharing. However, this commitment is not supported by binding legal obligations. Each regime defers to state sovereignty and allows for the potential of conflicts of interests within the regime, to varying extents. IRL balances the protection of refugees against the needs of the host state

\footnotetext{
146 Bueno de Mesquita, Kapilashrami and Mason Meier (n 68).

147 Ibid., 8.

148 IHR 2005 Review Committee (n 5) para. 98.

149 Ibid.
} 
population; GHL balances public health measures against international trade and traffic; IDL balances the need to provide assistance against the interest of the affected state to control the delivery and quality of aid, and IHRL accepts that not all rights can be absolute and the rights themselves need to balance against the realisation of other rights.

In terms of the interaction of substantive norms between the regimes, the rule at the centre of this article has been the obligation to provide assistance to refugees. However, rather than demonstrating a conflict of norms, our analysis has shown that each regime addresses the substantive rules consistently. First, all regimes make clear that territorial states must provide assistance to refugees, including the public health response to Covid-19. Second, other states and international organisations (in particular UNHCR and WHO) should assist the host state in doing so, although there is no obligation for the host state to accept assistance. Therefore, there is no conflict of norms, which means that this interaction should not be classed as a relationship of conflict.

Instead, what differs between the regimes is the content of the rules, that is, the standard or level of assistance or health provision that is expected of the territorial state. As discussed, IRL requires the host state to provide public relief to refugees on the same basis as to its nationals but no minimum standard of assistance or health care is set. IDL stipulates the provision of assistance on a needs basis, without discrimination, up to the level of resources available to the host state, with the duty to request assistance when that capacity is exceeded. GHL and IHRL (via the right to health) provide more detailed guidance and include measures for public health that should be taken before any public health emergency occurs. However, both accept that full compliance with these obligations is unlikely, and the realisation of the right to health is limited by the resources available to the state. Although the IHR 2005 appear to set more stringent, or at least more detailed, requirements than article 12 (c) of the ICESCR, in practice there is no enforcement but instead, a seeming acceptance that it may take much longer for developing states to meet the minimum requirements. In relation to the protection of refugees, GHL, IDL and IHRL suggest that the obligation to assist may actually be greater than that in IRL, requiring the state to prioritise assistance to vulnerable populations including refugees during a pandemic, particularly when the risk of infection is higher and the need for assistance greater in relation to refugees than the general population.

There is no fundamental conflict between these regimes, at least not in relation to these substantive obligations. This is not a situation 'where two norms [that] are both valid and applicable point to incompatible decisions so that a 
choice must be made between them.' ${ }^{150}$ Rather, the interaction between these regimes, at least on this issue, point to the first category of relationship identified by the ILC, one of interpretation. There is no primary or subsidiary regime; rather, all regimes apply equally to the question and one regime should not necessarily be preferred over another. None of the regimes creates any sense of hierarchy or seeks to displace or supersede other regimes through formal rules or guidance on regime interaction. Each regime, or at least the rule in question in each regime, has the same legal status; that is, the rule is not considered as a jus cogens norm in one regime that would 'override' the standard in the other regime(s). Moreover, while the principle of lex specialis may appear relevant given the greater specificity of the IHR 2005 standard, that principle applies where there is a conflict, with the more specific rule displacing the less specific. Here we suggest that there is no such conflict, so the rule does not apply to the regimes studied. Thus, the relationship(s) we have identified here is intended to complement and mutually reinforce each regime or rule: a symbiotic relationship.

With a focus on conflict between norms, the literature on regime interaction does not provide much guidance on how to reconcile regimes that are connected by a symbiotic relation. We argue that in these situations the principle of harmonisation should apply; that is, interpreting several relevant norms so as to give rise to 'a single set of compatible obligations' to the extent possible. This approach would rely on the norms in the applicable regimes to inform a single set of obligations. It would also adopt a contextualised approach to interpretation exploring how rules in different regimes interact in a specific context. Such an approach is supported by the shared humanitarian and protective purpose of these regimes and the overarching concern with the protection of persons and human dignity. This should drive the interpretation of the norms. However, each regime also recognises the limits of sovereignty and the need for balance; this too will be a relevant interpretative factor. One example of this interpretative approach is how IHRL can play an important interpretative role in relation to the IHR 2005, with the distinction made in CESCR's General Comment 14 between an unwillingness as against inability to meet standards also relevant to compliance with the IHR 2005 Annex 1. A state may be held to have complied with its IH R 2005 obligations where it has used best efforts within the resources available to do so. Another possible example of mutual reinforcement of norms is to interpret the IHR 2005 with reference to the standards provided by IHRL, as detailed in General Comment 14

$15^{\circ} \quad$ ILC (n 9) para. (2). 
and specific statements on COVID-19. Thus, any limits to economic, social and cultural rights as a result of PHSM should be proportionate, limited in time (and reviewed regularly) and strictly necessary to protect public health. This requirement could be incorporated in any review of the provisions of the IH R 2005 concerning temporary recommendations. ${ }^{151} \mathrm{~A}$ third example may be to interpret the obligation in article 23 of the 1951 Convention to reflect the recognition in IDL, GHL and IHRL that refugees, as particularly vulnerable groups, may require a higher level of assistance than the host population.

There are some challenges, or possibly opportunities, for a harmonisation approach to obligations in humanitarian emergencies, particularly in the light of calls for improved coherence and coordination in the response to covid19. ${ }^{152}$ First, as highlighted above, these regimes are characterized by weak or non-existent underlying obligations and compliance mechanisms. IRL and GHL impose limited or no reporting requirements on states and lack treaty monitoring bodies and sanctions for non-compliance. IDL contains rules that are not binding and even if so, do not set up any compliance or reporting mechanisms. Each of these regimes relies on political rather than legal enforcement, as in many fields of international law. IH RL does have treaty monitoring bodies, and in some cases, regional courts, but still relies on state consent to activate those mechanisms and on political support for compliance and enforcement, with treaty bodies issuing views rather than binding decisions. This means that the status of the rules and compliance with them is weak and states can 'get away' with not following the rules. Given their interests are less likely to be directly affected, this creates less impetus on states to resolve or clarify issues of regime interaction or to harmonise legal obligations.

This challenge is further increased by the absence of dispute settlement mechanisms that would have jurisdiction to hear disputes and to harmonise legal rules across regimes. There are no relevant dispute settlement bodies mandated or likely to be presented with opportunities to harmonise rules across regimes. The ICJ is a limited and to date not utilised mechanism in relation to IRL and GHL and only operates on a state-to-state basis. However, the advisory jurisdiction of the ICJ is triggered by a valid request from one of the major organs of the UN or a specialised agency on 'legal questions arising within the scope

151 Both the IHR 2005 Review Committee and the IPPPR discussed the need to clarify and strengthen the IHR 2005 provisions addressing temporary recommendations: IH R 2005 Review Committee (n 5 ) 41-45; IPPPR ( $\mathrm{n}_{4}$ ), 53 call for the wHO to give timely guidance as to what states should do in response to a declaration of a PHEIC.

152 Gian Luca Burci and Stefania Negri, 'Governing the Global Fight against Pandemics: The wHO, the International Health Regulations, and the Fragmentation of International Law' (2021) 53(2) New York University Journal of International Law and Politics 501, 514. 
of their activities. ${ }^{153}$ As noted above, the wHo has twice requested such opinions, once successfully and once unsuccessfully, demonstrating the scope for future requests that may include questions about the intersection of the scope of its activities with those of another international institution. IDL provides no dispute settlement mechanism at all. Individual judicial mechanisms exist only for IHRL and only in limited circumstances. This makes it unlikely that judicial institutions will be engaged and can attempt to reconcile the regimes and interpret the norms. We see some evidence that human rights treaty monitoring bodies seek to provide guidance and some harmonisation in the form of statements and general comments; however, these bodies still do not acknowledge the interpretative role they are engaged in "across" regimes and do not engage fully with other regimes and harmonising the rules. This is why a periodic review mechanism for state commitments under the IHR 2005 and a new dispute settlement mechanism would greatly increase the opportunities for consideration of how rules from different regimes can be used to reinforce an interpretation that favours protection.

Another distinguishing feature of these regimes is the well-defined and significant role of institutional, non-state actors in implementing the regimes, here WHO and UNHCR. This reflects the weak capacity of host states and the weak or non-existent obligations on other states to assist, combined with clear mandates for these organisations to take the lead. However, this provides an opportunity for these organisations to play a considerable role in harmonising obligations across the regimes, with any uncertainty or differences in the interpretation of rules worked out informally through institutional arrangements and interaction between actors, often via political channels, as seen in the WHO-UNHCR MoU. These organisations could also collaborate in the development of interpretative guidance or agree to harmonised standards drawing on all regimes that would assist states and other actors in implementation. Several institutions issued guidance during the pandemic; however, greater clarity is needed as to overlapping regimes and coordination in agreeing with common approaches.

A harmonisation approach to regime interaction will require some changes in thinking and practice to overcome the challenge of "siloing" across regimes. First, various actors need to move beyond their "comfort zones" and engage with other actors and regimes. ${ }^{154}$ This requires greater interaction and exchange of ideas and expertise between organisations such as WHO, UNCHR and human

153 Charter of the United Nations, 24 October 1945, art. 96(2).

154 See also Gian Luca Burci and Stefania Negri, 'Governing the Global Fight against Pandemics: The wHo, the International Health Regulations, and the Fragmentation of 
rights bodies. That this can happen is clear in the interaction between the WHO, UNHCHR and human rights treaty monitoring bodies in relation to the development of a WHO monitoring and reporting mechanism, as suggested by the IH R 2005 Review Committee. ${ }^{155}$ Moreover, the CESCR hinted at a harmonisation approach in its General Comment 14 and statement on COVID-19 but did not take the step of directly referencing wHO standards in its interpretation of article 12 of ICESCR on the right to health. Second, actors within the regimes need to develop a more context-driven and integrated approach to their own mandates that recognises the need to draw from and act consistently with other regimes. This will require expanding expertise beyond "core competency" areas of expertise. One example could be the inclusion of human rights expertise in the wHO, which is traditionally dominated by health experts narrowly defined, in particular, by medical doctors, and has limited human rights expertise. The Emergency Committee roster typically includes epidemiologists and virologists but does not include anyone with human rights expertise, making it unlikely that temporary recommendations will address human rights implications of public health measures. ${ }^{156}$ Any future reporting mechanism could also include information about human rights impacts of public health measures; similarly, current and future reviews of the implementation and effectiveness of the IHR 2005 could also consider human rights aspects and specific guidance on the protection and health care for refugees. Third, institutions should have clear mandates and suitable resources and funding for the harmonisation of rules with other regimes. Moreover, the role and responsibility of international organisations such as WHO and UNHCR in relation to human rights dimensions of their activities need to be considered.

\section{5}

Conclusion

The IPPPR concluded that 'the international system requires fundamental transformation to prevent a future pandemic' and a commitment to ensure

International Law' (2021) 53(2) New York University Journal of International Law and Politics 501, 516.

155 IHR 2005 Review Committee ( $\mathrm{n}_{5}$ ) 54.

${ }_{156}$ The list of members of the current Covid-19 committee is available at wHo ( $\mathrm{n} 70$ ). The only non-public health/virologist member is a public communications official from Singapore, a welcome step towards more inclusive decision-making. A proposal for the appointment of a human rights advisor in wHO emergencies teams has been made in the post-Covid-19 reviews, see Bueno de Mesquita, Kapilashrami and Mason Meier (n 68) 7 . 
that the new system 'is coordinated, connected, fast-moving, accountable, just, and equitable.157 While the focus of this review, and the IHR 2005 review, is mainly on GHL and the WHO, the reviews make three things clear. First, the scope of the challenge of the pandemic is such that none of these regimes could be expected to function well (if at all); however, in many respects, the challenge has been increased by the weakness of the relevant rules and the failure of states to comply with their obligations or commitments. Second, the enormous impact of CoviD-19 is not restricted to health but has been economic and social, fundamentally affecting all aspects of life, particularly for already vulnerable populations such as refugees. Third, pandemics of the scale of COVID-19 are likely to occur in future. Therefore, any transformation of the GHL framework must consider how the regimes that address the protection of refugees and other vulnerable populations interact (or not) with GHL and use this as an opportunity to provide a more harmonised approach to respond to future pandemics. This includes reforming the legal and institutional framework for $\mathrm{GHL}$, for example, by ensuring that any amendments proposed to the IHR 2005 recognise the importance of IHRL, the inclusion of human rights expertise on any redesigned Emergency Committee and more detail on how best to protect refugee populations beyond recognising they are particularly vulnerable. Humanitarian emergencies will trigger multiple legal regimes and institutions and we need to enhance the way those regimes and their institutions interact and mutually reinforce one another. This may mean a shift in the literature from a focus on regime conflict to adopting - at least in this context - a symbiotic approach to regime interaction that requires harmonisation of norms rather than managing conflicts.

157 IPPPR (n 4) 4, 9. 